\title{
An Event Study Analysis of Thailand's 2019 General Election: A Long Window of Multiple Sub-events
}

\author{
Anya Khanthavit ${ }^{1}$ \\ ${ }^{1}$ Faculty of Commerce and Accountancy, Thammasat University, Bangkok, Thailand \\ Correspondence: Anya Khanthavit, Faculty of Commerce and Accountancy, Thammasat University, 2 Prachan Road, \\ Bangkok 10200, Thailand. Tel: 66-2-696-5752. E-mail: akhantha@tu.ac.th \\ Received: May 6, 2020 \\ Accepted: July 2, 2020 \\ Online Published: July 12, 2020 \\ doi:10.5430/ijfr.v11n4p502 \\ URL: https://doi.org/10.5430/ijfr.v11n4p502
}

\begin{abstract}
This study extends the conditional regression model for event study analyses to include sub-events related to the events under investigation. The extended model ensures that all relevant sub-events are included in the event window and their significant effects are not averaged out. The model is applied to analyze the effects of Thailand's 2019 general election on stock market performance. Information on the election day and the sub-event days before and after the election day contributed to the significant election effects. The inclusion of sub-events in the analysis is important and useful.
\end{abstract}

Keywords: conditional regression, market efficiency, return behavior

\section{Introduction}

A general election is an important event to which investors give considerable attention. Through their votes, investors can influence the outcome; the media, poll makers, and analysts actively collect and disseminate information about the election to the market; and, as the election date approaches and it becomes clearer and clearer which party will win the election, investors gradually update their expectations about the party's proposed economic policies and their implications for stocks (Panzalis, Stangeland, \& Turtle, 2000).

The effects of general elections on stock market performance have been studied extensively by researchers. The election date is known with certainty once it is announced; only the outcome is unknown (Gemmill, 1992). Stock movement surrounding the election date reveals how investors revise their expectations and react to the realizations. Event study analyses are a popular approach to test these effects. For example, for developed markets, Niederhoffer, Gibbs, and Bullock (1970), Oehler, Walker, and Wendt (2013), and Obradovic and Tomic (2017) conducted studies in the U.S.A., while Leblang and Mukherjee (2005) studied both the U.S.A. and the U.K. For emerging markets, studies were conducted for Indonesia, Malaysia, Pakistan, and Taiwan by Imelda, Siregar, and Anggraeni (2014), Redzwan, Musa, Latip, Latif, and Rahman (2019), Khan, Jafri, Baig, Shaique, and Usman (2017), and Hung (2011), respectively. Moreover, Nimkhunthod (2007) performed a study on the Thai market, and Wong and Hooy (2016) studied the Indonesian, Malaysian, and Thai markets. International evidence was reported by Panzalis et al. (2000) and Wang, Lee, and Lin (2008). The results in terms of performance direction and significance are inconsistent from one country or election to another.

Consistent results should not be expected. In most cases, much uncertainty about the outcomes is resolved prior to the election day (Panzalis el al., 2000). Therefore, significant abnormal price performance is unobserved. Only when the outcome is unanticipated does significant reaction manifest (Butler \& McNertney, 1991).

Obradovic and Tomic (2017) cautioned that event windows for election studies were asymmetric. If the outcome is anticipated, the window should cover several days prior to the election day in order to include informative sub-events such as polls and debates. It is important to note that surprising sub-events may arise before the election day and lead to a change in the outcome. For example, the terrorist incident in Spain that happened three days before the 2004 election day caused a reverse of expectations. Against all the predictions and polls, the opposition party won the election (Castells \& Trillas, 2013).

Even if the market was efficient, all the information about the election is not necessarily revealed on the election day because it is not known with certainty which party will win the election. The results are not decisive, and the full vote counts can delay (Nippani \& Medlin, 2002). The result declared by the election commission is challenged and is 
resolved by the court on a much later date (Chandra, 2015). Oehler et al. (2013) added that more election information could come to the U.S. market after the inauguration, as the new president announced the road map for his term.

Garfinkel, Glazer, and Lee (1999) were aware that all elections were different, such that studies could not treat them in the same way. Each election should be analyzed individually and consistently with a unique series of informative sub-events. In previous studies, Castells and Trillas (2013) added a pre-election sub-event, while Nippani and Medlin (2002) and Chandra (2015) did post-election sub-events in their event windows. However, no researchers have ever incorporated a full set of informative pre- and post-election sub-events.

With respect to the information induced by sub-events before and after the event day, this study proposes that event study analyses should extend the event window and that stock price performance on the days surrounding the event as well as sub-event days should be examined. The method extends the conditional regression model (Izan, 1978) by adding performance dummies for the pre- and post-election sub-events.

It is difficult for researchers to choose appropriate pre- and post-event windows. Nazir, Younus, Kaleem, and Anwar (2014) caution against long pre-event windows to avoid possible confounding events. Similarly, a window that is too short is not recommended, as researchers are unable to analyze impacts if the window is too short (Khanthavit, 2020). Similar reasoning is applied to the choice of post-event windows. The proposed extension helps to improve the choices for the pre- and post-event windows. It ensures that all relevant and informative election sub-events are covered. It also helps to reduce biasedness problems in parameter estimates when the pre-event window does not cover pre-election sub-events and those days are included in parameter estimation. Moreover, the coefficients for performance dummies for pre- and post-election sub-events provide researchers with detailed information on how the market responds to each event and sub-event, thus reducing the chances of incorrect conclusions of the study.

The study applies the proposed method to analyze the performance variables in the Stock Exchange of Thailand (SET) in the period surrounding Thailand's 2019 general election. The market is chosen because Thailand is one of the world's leading emerging markets. In December 2019, the market capitalization of SET was 569 billion U.S. dollars. According to the World Federation of Exchanges (2019), the SET ranked eleventh among markets in the Asia-Pacific region and was the twenty-fifth largest market in the world. Thailand's politics is interesting to political researchers for the unique "Thai-style democracy" under which the military bloodlessly seized power from purportedly corrupt elected governments, ended the prolonged, widespread, and violent anti-government protests, and promised to return the country to democracy (Maisrikrod, 2007). The 2019 general election is the first election following the most recent May 2014 coup. However, few researchers, such as Nimkhunthod (2007) and Wong and Hooy (2016), were interested in studying election effects on Thai stocks. This study helps to reduce the paucity of literature on the Thai market.

The 2019 election that was scheduled for Sunday, March 24, 2019, was interesting. Important sub-events occurred both before and after the election day. Before the election day, General Prayut Chanocha - the junta leader and prime minister (PM) of the incumbent government-announced on February 8, 2019, that he accepted the Palang Pracharath Party (PPRP)'s invitation to become its candidate for PM. In retrospect, this incident should have ensured that the PPRP ran the next government. This is because the new constitution - drafted by the junta-appointed constitution drafting committee-imposed the combined National Assembly of 250 junta-appointed senators and 500 members of the House of Representatives voted on the PM. It is likely that the senators supported Chanocha. An opposition alliance against the PPRP had little chance of getting enough votes to win (Tanakasempipat \& Thepgumpanat, 2019).

Full information on who would run the government and what economic policies would be implemented was not revealed on the election day, but much later, after a series of sub-events. It turned out that the competition was very close. The vote count was delayed and the official election results were announced for the constituency and party-list representatives on May 7 and 8, 2019, respectively. The results were not decisive. While the PPRP received the highest number of 8.43-million constituency votes, the Phue Thai Party had the highest number of representatives (i.e., 136).

After a long negotiation, the PPRP could form the government with its 18 alliance parties. On May 29, 2019, Chuan Leekpai from the Democratic Party (one of the PPRP's influential alliances) was elected in the House of Representatives to be the President of the National Assembly of Thailand and the Speaker of the House of Representatives. Chanocha was voted as the PM on June 5, 2019. Eventually, the new cabinet was announced in Royal Gazette on July 10, 2019. The series of the 2019 election sub-events is summarized in Table 1. Column 1 shows the days in which sub-events occurred and Column 3 describes the sub-events. Two occurrence days for the election and the first parliament session are holidays. The corresponding sub-event days in Column 2 are different and set for the following trading days because the stock market is closed (Ahmed, 2017). 
Table 1. Thailand's 2019 general-election sub-events

\begin{tabular}{|c|c|c|}
\hline Occurrence Day & $\begin{array}{c}\text { Sub-event Day } \\
\text { (Sub-event Number) }\end{array}$ & Description of Sub-event \\
\hline Friday, February 8, 2019 & $\begin{array}{l}\text { Friday, February 8, } 2019 \\
\qquad(-1)\end{array}$ & $\begin{array}{l}\text { General Prayut Chanocha became the Palang Pracharath Party's candidate for Prime } \\
\text { Minister. }\end{array}$ \\
\hline Sunday, March 24, 2019 & $\begin{array}{l}\text { Monday, March 25, } 2019 \\
(0)\end{array}$ & The 2019 general election took place. \\
\hline Tuesday, March 26, 2019 & - & The first unofficial results of 350 constituencies were given by the Election Commission. \\
\hline Thursday, March 28, 2019 & - & $\begin{array}{l}\text { The second unofficial results of } 350 \text { constituencies were given by the Election } \\
\text { Commission. }\end{array}$ \\
\hline Tuesday, May 7, 2019 & - & The official results for the constituency representatives were released. \\
\hline Wednesday, May 8, 2019 & $\begin{array}{l}\text { Wednesday, May 8, } 2019 \\
\qquad(+1)\end{array}$ & The official results for the party-list representatives were released. \\
\hline Saturday, May 25, 2019 & $\begin{array}{l}\text { Monday, May 27, } 2019 \\
(+2)\end{array}$ & $\begin{array}{l}\text { The parliament convened its first session and voted Chuan Leekpai from the Democratic } \\
\text { Party, one of the Palang Pracharath Party's alliance, as the President of the National } \\
\text { Assembly of Thailand and the Speaker of the House of Representatives. }\end{array}$ \\
\hline Wednesday, June 5, 2019 & $\begin{array}{l}\text { Wednesday, June } 5,2019 \\
\qquad(+3)\end{array}$ & $\begin{array}{l}\text { General Prayut Chanocha was elected as Prime Minister by the combined national } \\
\text { assembly. }\end{array}$ \\
\hline Wednesday, July 10, 2019 & $\begin{array}{l}\text { Wednesday, July 10, } 2019 \\
(+4)\end{array}$ & The new cabinet was announced in Royal Gazette. \\
\hline
\end{tabular}

\section{Method}

\subsection{Identification of Significant Abnormal Performance}

Let $\tilde{y}_{t}$ be the performance variable in period $t$. In this study, the performance variable is the stock return. It is the sum of the expected or normal return $\mu_{t}$ and the unexpected or abnormal return $\tilde{e}_{t}$, as in Equation (1).

$$
\tilde{y}_{t}=\mu_{t}+\tilde{e}_{t}
$$

If the event is significant, the abnormal return $\tilde{e}_{t}$ must be different from zero (Fama, Fisher, Jensen, \& Roll, 1969). Izan (1978) modified Fama et al.'s (1969) method to measure abnormal returns by parameterizing the variables in the conditional regression model in Equation (2):

$$
\tilde{y}_{\mathrm{t}}=\mu_{\mathrm{t}}+\sum_{\mathrm{a}=-\mathrm{A}_{\text {Pre }}}^{-1} \delta_{\mathrm{a}} \mathrm{D}_{\mathrm{t}}^{\mathrm{a}}+\delta_{0} \mathrm{D}_{\mathrm{t}}^{0}+\sum_{\mathrm{b}=+1}^{+\mathrm{B}_{\text {Post }}} \delta_{\mathrm{b}} \mathrm{D}_{\mathrm{t}}^{\mathrm{b}}+\tilde{\mathrm{e}}_{\mathrm{t}},
$$

where $t=-N, \ldots,-A_{\text {Pre }}, \ldots,-1,0,+1, \ldots,+B_{\text {Post }}$. With respect to Fama et al. (1969), the period from $t=-N$ to $t=-A_{\text {Pre }}-1$ is the estimation window, the period from $t=-A_{\text {Pre }}$ to $t=+B_{\text {Post }}$ is the event window, and the period $t=0$ is the event period. The dummy variable $D_{t}^{\tau=a, 0, b}$ is 1.00 if the period $t$ is $\tau$. Otherwise, it is 0.00 . The regression coefficient $\delta_{\tau}$ measures the abnormal variables in period $\tau$.

The pre- and post-election event windows, from $t=-A_{\text {Pre }}-1$ to $t=-1$ and $t=+1$ to $t=+B_{\text {Post }}$, are chosen by researchers. Typical window lengths can range from 21 to 121 days and 25 to 125 months for daily and monthly studies, respectively, (Peterson, 1989). The lengths must be short enough to avoid confounding events (Nazir et al., 2014), but they must be long enough to cover all important pre- and post-election sub-events (Khanthavit, 2020).

This study proposes to extend the Izan model in Equation (2) to incorporate important pre- and post-election sub-events into the analysis. The pre-election sub-event windows lie within the period from $t=-A_{\text {Pre }}-1$ to $t=-1$, while the post-election windows are within the period from $t=+1$ to $t=+B_{\text {Post }}$. Unlike previous studies, the event windows are not predetermined, but depend on the pre- and post-election sub-events. Problems of the misspecification of window lengths are reduced.

Let $\mathrm{i}=-1, \ldots,-\mathrm{I}$ and $\mathrm{j}=+1, \ldots,+\mathrm{J}$ be the pre- and post-election sub-events, where sub-events $\mathrm{i}=-1$ and $\mathrm{j}=+1$ are the ones that lie closest to event 0 (the election event). 


$$
\begin{aligned}
& \tilde{\mathrm{y}}_{\mathrm{t}}=\mu_{\mathrm{t}}+\sum_{\mathrm{a}=-\mathrm{A}_{\text {Pre }}}^{-1} \delta_{-\mathrm{I}, \mathrm{a}} \mathrm{D}_{\mathrm{t}}^{-\mathrm{I}, \mathrm{a}}+\delta_{-\mathrm{I}} \mathrm{D}_{\mathrm{t}}^{-\mathrm{I}}+\sum_{\mathrm{b}=+1}^{+\mathrm{B}_{\text {Post }}} \delta_{-\mathrm{I}, \mathrm{b}} \mathrm{D}_{\mathrm{t}}^{-\mathrm{I}, \mathrm{b}}+\cdots \\
& +\sum_{\mathrm{a}=-\mathrm{A}_{\text {Pre }}}^{-1} \delta_{-1, \mathrm{a}} \mathrm{D}_{\mathrm{t}}^{-1, \mathrm{a}}+\delta_{-1} \mathrm{D}_{\mathrm{t}}^{-1}+\sum_{\mathrm{b}=+1}^{+\mathrm{B}_{\text {Post }}} \delta_{-1, \mathrm{~b}} \mathrm{D}_{\mathrm{t}}^{-1, \mathrm{~b}} \\
& +\sum_{\mathrm{a}=-\mathrm{A}_{\text {Pre }}}^{-1} \delta_{0, \mathrm{a}} \mathrm{D}_{\mathrm{t}}^{0, \mathrm{a}}+\delta_{0} \mathrm{D}_{\mathrm{t}}^{0}+\sum_{\mathrm{b}=+1}^{+\mathrm{B} \text { Post }} \delta_{0, \mathrm{~b}} \mathrm{D}_{\mathrm{t}}^{0, \mathrm{~b}} \\
& +\sum_{\mathrm{a}=-\mathrm{A}_{\text {Pre }}}^{-1} \delta_{+1, \mathrm{a}} \mathrm{D}_{\mathrm{t}}^{+1, \mathrm{a}}+\delta_{+1} \mathrm{D}_{\mathrm{t}}^{+1}+\sum_{\mathrm{b}=+1}^{+\mathrm{B}_{\text {Post }}} \delta_{+1, \mathrm{~b}} \mathrm{D}_{\mathrm{t}}^{+1, \mathrm{~b}}+\cdots \\
& +\sum_{\mathrm{a}=-\mathrm{A}_{\text {Pre }}}^{-1} \delta_{+\mathrm{J}, \mathrm{a}} \mathrm{D}_{\mathrm{t}}^{+\mathrm{J}, \mathrm{a}}+\delta_{+\mathrm{J}} \mathrm{D}_{\mathrm{t}}^{+\mathrm{J}}+\sum_{\mathrm{b}=+1}^{+\mathrm{B}_{\text {Post }}} \delta_{+\mathrm{J}, \mathrm{b}} \mathrm{D}_{\mathrm{t}}^{+\mathrm{J}, \mathrm{b}} \\
& +\mu_{\mathrm{t}}^{\mathrm{W}} \mathrm{D}_{\mathrm{t}}^{\mathrm{W}}+\tilde{\mathrm{e}}_{\mathrm{t}} .
\end{aligned}
$$

The dummy variables and coefficients are defined in a way that is similar to those in Equation (2). They are associated with the event 0 and sub-events $i=-1, \ldots,-I$ and $j=+1, \ldots,+\mathrm{J}$. The full event window is from $A_{\text {Pre }}$ days before the pre-election sub-event $-\mathrm{I}$ to $\mathrm{B}_{\text {Post }}$ days after the post-election sub-event $+\mathrm{J}$. The estimation window covers $\mathrm{N}$ days prior to the first day of the full event window. The periods of $\mathrm{A}_{\text {Pre }}+\mathrm{B}_{\text {Post }}+1$ days surrounding the event and sub-events $\mathrm{m}, 0$, and $\mathrm{n}$ are the event and sub-event windows, respectively. The numbers of $A_{\text {Pre }}$ and $B_{\text {Post }}$ days are necessarily much smaller than those in Equation (2).

The event and sub-event windows may not be next to each other. With respect to the expected value $\mu_{t}$, the abnormal performance on the days in the full window but not a part of the event or sub-event windows can be significant if the election induces structural changes. The study adds a term $\mu_{t}^{W} D_{t}^{W}$ to separate the effects of general structural changes from the effects of specific events and sub-events. The dummy variable $D_{t}^{W}$ is 1.00 if day $t$ is the day between the event and sub-events and lying within the full event window. Otherwise, it is 0.00 . The coefficient $\mu_{\mathrm{t}}^{\mathrm{W}}$ measures the abnormal return vis-à-vis the dummy variable $\mathrm{D}_{\mathrm{t}}^{\mathrm{W}}$.

The performance variables in the periods surrounding the sub-events offer detailed information specific to the sub-events. This information is unknown to researchers under the specification in Equation (2). The information would be incorrectly included in the estimation of the expected value $\mu_{t}$ if the full event window is short and does not cover all the sub-events. The estimate for $\mu_{t}$ is biased. Even if the full event window is sufficiently long, the information is reported as the average abnormal performance for the pre- and post-election window. Moreover, significant performance can take on different signs so that the effects cancel. It is possible that the averages are not significant, leading to incorrect conclusions of non-significance.

\subsection{The Model for Expected Return}

The expected return $\mu_{\mathrm{t}}$ is unobserved; it must be estimated. There are alternative choices for its specification (Peterson, 1989; Khanthavit, 2020). The mean-adjusted specification, under which the expected return $\mu_{\mathrm{t}}$ is a constant $\bar{\mu}$, is used in this study because it can perform as well as the alternatives (Brown \& Warner, 1985).

The abnormal return $\mu_{\mathrm{t}}^{\mathrm{W}}$ can vary over time. The time varying $\mu_{\mathrm{t}}^{\mathrm{W}}$ can be estimated by adding coefficients for the dummy variable $D_{t}^{W}$ into Equation (3). However, the number of coefficients to be estimated would be large. The estimation suffers from falling degrees of freedom and imprecise estimates of the coefficients. In addition, the time varying $\mu_{t}^{\mathrm{W}}$ does not offer insightful information because it does not link directly to the event or sub-events. For this reason, the study imposes that the time varying $\mu_{\mathrm{t}}^{\mathrm{W}}$ is a constant $\bar{\mu}^{\mathrm{W}}$.

Given the specifications for the expected return $\mu_{t}$ and abnormal return $\mu_{t}^{W}$, Equation (3) becomes Equation (4) below.

$$
\begin{aligned}
& \tilde{\mathrm{y}}_{\mathrm{t}}=\bar{\mu}+\sum_{\mathrm{a}=-\mathrm{A}_{\text {Pre }}}^{-1} \delta_{-\mathrm{I}, \mathrm{a}} \mathrm{D}_{\mathrm{t}}^{-\mathrm{I}, \mathrm{a}}+\delta_{-\mathrm{I}} \mathrm{D}_{\mathrm{t}}^{-\mathrm{I}}+\sum_{\mathrm{b}=+1}^{+\mathrm{B}_{\text {Post }}} \delta_{-\mathrm{I}, \mathrm{b}} \mathrm{D}_{\mathrm{t}}^{-\mathrm{I}, \mathrm{b}}+\cdots \\
& +\sum_{\mathrm{a}=-\mathrm{A}_{\text {Pre }}}^{-1} \delta_{-1, \mathrm{a}} \mathrm{D}_{\mathrm{t}}^{-1, \mathrm{a}}+\delta_{-1} \mathrm{D}_{\mathrm{t}}^{-1}+\sum_{\mathrm{b}=+1}^{+\mathrm{B}_{\text {Post }}} \delta_{-1, \mathrm{~b}} \mathrm{D}_{\mathrm{t}}^{-1, \mathrm{~b}} \\
& +\sum_{\mathrm{a}=-\mathrm{A}_{\text {Pre }}}^{-1} \delta_{0, \mathrm{a}} \mathrm{D}_{\mathrm{t}}^{0, \mathrm{a}}+\delta_{0} \mathrm{D}_{\mathrm{t}}^{0}+\sum_{\mathrm{b}=+1}^{+\mathrm{B}_{\text {Post }}} \delta_{0, \mathrm{~b}} \mathrm{D}_{\mathrm{t}}^{0, \mathrm{~b}} \\
& +\sum_{\mathrm{a}=-\mathrm{A}_{\text {Pre }}}^{-1} \delta_{+1, \mathrm{a}} \mathrm{D}_{\mathrm{t}}^{+1, \mathrm{a}}+\delta_{+1} \mathrm{D}_{\mathrm{t}}^{+1}+\sum_{\mathrm{b}=+1}^{+\mathrm{B}_{\text {Post }}} \delta_{+1, \mathrm{~b}} \mathrm{D}_{\mathrm{t}}^{+1, \mathrm{~b}}+\cdots \\
& +\sum_{\mathrm{a}=-\mathrm{A}_{\text {Pre }}}^{-1} \delta_{+\mathrm{J}, \mathrm{a}} \mathrm{D}_{\mathrm{t}}^{+\mathrm{J}, \mathrm{a}}+\delta_{+\mathrm{J}} \mathrm{D}_{\mathrm{t}}^{+\mathrm{J}}+\sum_{\mathrm{b}=+1}^{+\mathrm{B}_{\text {Post }}} \delta_{+\mathrm{J}, \mathrm{b}} \mathrm{D}_{\mathrm{t}}^{+\mathrm{J}, \mathrm{b}} \\
& +\bar{\mu}^{\mathrm{W}} \mathrm{D}_{\mathrm{t}}^{\mathrm{W}}+\tilde{\mathrm{e}}_{\mathrm{t}} .
\end{aligned}
$$




\subsection{Identification of the Event Date}

The election date is certain once it has been announced. In most countries, general elections are held on Saturdays or Sundays. Saturdays and Sundays are holidays on which stock markets are closed. Event study analyses consider the day as the occurrence day. The event day is the next trading day because the market opens and investors have the opportunity to trade on new information on the election outcome (Ahmed, 2017). This study identifies the occurrence days for the event and sub-event days if the event and sub-events occur on trading days. However, if they occur on holidays, the event and sub-event days are the next trading days.

\subsection{Length of the Pre- and Post-Event and Sub-event Windows}

In this study, the full event window covers the election event as well as pre- and post-election sub-events. Each event and sub-event is assigned a window of its own. The individual windows cannot be very long. Otherwise, the windows overlap and it is not clear which sub-event contributes to abnormal returns. This study follows researchers such as Khan et al. (2017) to set the pre- and post-event windows to five days, constituting an 11-day window for the event and sub-events.

\subsection{Length of the Estimation Window}

For the accuracy of the estimates, Salinger (1992) recommends long estimation windows. Typical lengths of the estimation window range from 100 to 300 days (Peterson, 1989). This study chose 300 days, following the researcher Khanthavit (2020).

\subsection{Empirical Model}

This study examines the effects of the 2019 general election on stock market performance. From Table 1, there are nine election-related events and sub-events. Given an 11-day event window, the study is interested in only six of them, associated with the event and sub-event days in Column 2. The first and second unofficial announcements are not considered because the sub-events are covered by the post-election window. The release of the outcome for the constituency representatives is not included because the sub-event is a part of the release of the outcome for the party-list representatives, which occurred one day later. The two releases are, therefore, the same sub-event.

The event and sub-event days are the same as the occurrence days, except for the election day and the day of the first parliament session. For the two exceptions, the event days are the following trading days because the occurrence days were holidays. The day of the first parliament session and the day Chanocha was voted for PM are close, and the post-sub-event window of the former overlaps the pre-sub-event window of the latter. The full-event and estimation windows were 111 and 300 days, respectively, constituting a 411-day full sample period.

The number of parameters to be estimated can be large if abnormal performance in the event and sub-event windows is measured daily. To achieve a practical number, the study groups the five days of pre- and post-event and sub-event windows into a period of five days. The coefficients $\delta_{-\mathrm{i}, \mathrm{a}}, \delta_{-0, \mathrm{a}}, \delta_{+\mathrm{j}, \mathrm{a}}, \delta_{-\mathrm{i}, \mathrm{b}}, \delta_{-0, \mathrm{~b}}$, and $\delta_{+\mathrm{j}, \mathrm{b}}$ are interpreted as being the average abnormal stock performance for the five-day window; the coefficients $\delta_{\mathrm{i}}, \delta_{0}$, and $\delta_{+\mathrm{j}}$ are the abnormal performance on the event and sub-event days. Owing to the grouping, the number of coefficients decreases to nineteen. The empirical model is shown in Equation (5).

$$
\begin{aligned}
& \tilde{y}_{\mathrm{t}}=\bar{\mu}+\delta_{-1, \mathrm{a}} \mathrm{D}_{\mathrm{t}}^{-1, \mathrm{a}}+\delta_{-1} \mathrm{D}_{\mathrm{t}}^{-1}+\delta_{-1, \mathrm{~b}} \mathrm{D}_{\mathrm{t}}^{-1, \mathrm{~b}}+\delta_{0, \mathrm{a}} \mathrm{D}_{\mathrm{t}}^{0, \mathrm{a}}+\delta_{0} \mathrm{D}_{\mathrm{t}}^{0}+\delta_{0, \mathrm{~b}} \mathrm{D}_{\mathrm{t}}^{0, \mathrm{~b}} \\
& +\delta_{+1, \mathrm{a}} \mathrm{D}_{\mathrm{t}}^{+1, \mathrm{a}}+\delta_{+1} \mathrm{D}_{\mathrm{t}}^{+1}+\delta_{+1, \mathrm{~b}} \mathrm{D}_{\mathrm{t}}^{+1, \mathrm{~b}}+\delta_{+2, \mathrm{a}} \mathrm{D}_{\mathrm{t}}^{+2, \mathrm{a}}+\delta_{+2} \mathrm{D}_{\mathrm{t}}^{+2} \\
& +\delta_{+3, \mathrm{a}} \mathrm{D}_{\mathrm{t}}^{+3, \mathrm{a}}+\delta_{+3} \mathrm{D}_{\mathrm{t}}^{+3}+\delta_{+1, \mathrm{~b}} \mathrm{D}_{\mathrm{t}}^{+3, \mathrm{~b}}+\delta_{+4, \mathrm{a}} \mathrm{D}_{\mathrm{t}}^{+4, \mathrm{a}}+\delta_{+4} \mathrm{D}_{\mathrm{t}}^{+4}+\delta_{+1, \mathrm{~b}} \mathrm{D}_{\mathrm{t}}^{+4, \mathrm{~b}} \\
& +\bar{\mu}^{\mathrm{W}} \mathrm{D}_{\mathrm{t}}^{\mathrm{W}}+\tilde{\mathrm{e}}_{\mathrm{t}} .
\end{aligned}
$$

The term $\delta_{+2, \mathrm{~b}} \mathrm{D}_{\mathrm{t}}^{+2, \mathrm{~b}}$ is excluded, as it is the same as the term $\delta_{+3, \mathrm{a}} \mathrm{D}_{\mathrm{t}}^{+3, \mathrm{a}}$. The subscripts/superscripts $-1, \ldots,+4$ of the coefficients (dummy variables) represent the event and sub-events described in Table 1.

\subsection{Model Estimation and Hypothesis Tests}

Equation (5) is estimated using ordinary least squares (OLS) regression. The coefficients are $\bar{\mu}, \delta_{-\mathrm{i}, \mathrm{a}}, \delta_{0, \mathrm{a}}, \delta_{+\mathrm{j}, \mathrm{a}}$, $\delta_{-\mathrm{i}}, \delta_{0}, \delta_{+\mathrm{j}}, \delta_{-\mathrm{i}, \mathrm{b}}, \delta_{0, \mathrm{~b}}, \delta_{+\mathrm{j}, \mathrm{b}}$, and $\bar{\mu}^{\mathrm{W}}$. If stocks respond to the election, at least one of the $\delta$ coefficients must be different from zero. The positive/negative coefficients for the pre- and post-sub-event windows suggest that the 
sub-events are favorable/unfavorable. After the sub-event, the information pertaining to the sub-event should fully reveal that the coefficient for the post-sub-event window is positive (Shaik, 2017). The positive coefficient follows the uncertain information hypothesis (UIH) (Brown, Harlow, \& Tinic, 1988). Moreover, if the effects of the event or sub-events are permanent, the average $\frac{5 \delta_{\mathrm{k}, \mathrm{a}}+\delta_{\mathrm{k}}+5 \delta_{\mathrm{k}, \mathrm{b}}}{6}$ must be different from zero. $\mathrm{k}=-1,0, \ldots,+4$. The hypothesis test will be conducted from Newey and West's (1994) heteroscedasticity and autocorrelation consistent (HAC) covariance matrix.

Previous studies, for example, Lumjiak, Treepongkaruna, Wee, and Brooks (2016), have checked for equal abnormal performance before and after the event day. Inequality may be interpreted as indicating structural changes (Lumjiak et al., 2016) or information dissemination (Obradovic \& Tomic, 2017). This study tests the equality hypothesis. Under the null, $\delta_{\mathrm{k}, \mathrm{a}}-\delta_{\mathrm{k}, \mathrm{b}}=0$.

\section{The Data}

This study examines the stock returns on days surrounding the event and sub-event days relating to Thailand's 2019 general election. With respect to the six event and sub-event days in Table 1, the 411-day sample period is from October 19, 2017, to July 18, 2019, and the 111-day full event window covers the days from February 1, 2019, to July 18, 2019. The performance variable is log return computed from the logged differences of the closing total-return indexes of the SET portfolio index. The stock index data were retrieved from the SET database.

Column 2 of Table 2 reports the descriptive statistics of the SET index return. The variable is negatively skewed and fat-tailed. The normality hypothesis is rejected by the Jarque-Bera test. The return shows no autocorrelation. The Dickey-Fuller t-statistic is negatively large; thus, the non-stationarity hypothesis is rejected.

Although the return is not distributed normally, OLS regression can be used. Because the event and sub-events are exogenous, the OLS estimator is consistent and unbiased (Greene, 2018). Newey and West's (1994) HAC works for hypothesis testing in cases in which return autocorrelation and heteroscedasticity are present and absent.

Table 2. Descriptive statistics

\begin{tabular}{|c|c|c|c|c|}
\hline Statistic & Return & Volatility & Trading Volume & $\begin{array}{c}\text { Net Foreign-Buying } \\
\text { Volume }\end{array}$ \\
\hline Average & $1.46 \mathrm{E}-04$ & 0.0055 & 0.0031 & $-3.48 \mathrm{E}-05$ \\
\hline Standard Deviation & 0.0067 & 0.0027 & 8.99E-04 & $1.33 \mathrm{E}-04$ \\
\hline Skewness & -0.3120 & 1.9148 & 3.1572 & 0.3159 \\
\hline Excess Kurtosis & 1.2191 & 8.8357 & 25.8792 & 4.6301 \\
\hline Jarque-Bera Statistic & $32.1221^{* * *}$ & $1.59 \mathrm{E}+03^{* * *}$ & $1.22 \mathrm{E}+04^{* * *}$ & $3.74 \mathrm{E}+02^{* * *}$ \\
\hline AR(1) Coefficient & 0.0358 & $0.1337^{* * *}$ & $0.4070^{* * *}$ & $0.4360^{* * * *}$ \\
\hline $\begin{array}{c}\text { Augmented } \\
\text { Dickey-Fuller t-Statistic } \\
\text { (Lag Number) }\end{array}$ & $\begin{array}{r}-19.5087^{* * * *} \\
(0)\end{array}$ & $\begin{array}{r}-17.6556^{* * *} \\
(0)\end{array}$ & $\begin{array}{r}-6.0699^{\text {*** }} \\
\text { (3) }\end{array}$ & $\begin{array}{r}-6.6280^{* * * *} \\
(2)\end{array}$ \\
\hline
\end{tabular}

Note: ${ }^{* * *}=$ Significance at the $99 \%$ confidence level. The sample is from October 19, 2017, to July 18, 2019 (411 observations).

\section{Empirical Results}

\subsection{The Conditional Regression Approach}

Before the study proceeds to report the results for the extended, conditional regression approach, it estimates the model by Izan's (1978) traditional approach. The results are shown in Table 3. 
Table 3. Abnormal return in the period surrounding the election

\begin{tabular}{|c|c|c|c|c|}
\hline \multirow[b]{2}{*}{ Event } & \multirow{2}{*}{$\begin{array}{c}\text { Days with respect to the } \\
\text { Event }\end{array}$} & \multirow{2}{*}{$\begin{array}{l}\text { 5-Day Pre and Post } \\
\text { Event Windows }\end{array}$} & \multicolumn{2}{|c|}{ 20-Day Pre and Post Event Windows } \\
\hline & & & $\begin{array}{c}\text { One Window of } 20 \\
\text { Days }\end{array}$ & Four Windows of 5 Days \\
\hline \multirow{11}{*}{ General election. } & -15 to -20 & N.A. & \multirow{3}{*}{$-4.19 \mathrm{E}-05$} & 8.70E-04 \\
\hline & -11 to -15 & N.A. & & -0.0016 \\
\hline & -6 to -10 & N.A. & & $7.16 \mathrm{E}-04$ \\
\hline & -5 to -1 & $-1.79 \mathrm{E}-04$ & \multirow{3}{*}{$0.0075^{* * *}$} & $-1.79 \mathrm{E}-04$ \\
\hline & Day 0 on $02 / 08 / 2019$ & $0.0075^{* * *}$ & & $0.0075^{* * *}$ \\
\hline & +1 to +5 & $-9.10 \mathrm{E}-04$ & & $-9.10 \mathrm{E}-04$ \\
\hline & +6 to +10 & N.A. & \multirow{3}{*}{0.0010} & 0.0011 \\
\hline & +11 to +15 & N.A. & & $0.0036^{* * *}$ \\
\hline & +16 to +20 & N.A. & & $3.60 \mathrm{E}-04$ \\
\hline & $\mathrm{H}_{0}$ : Average $=0$ & $1.87 \mathrm{E}-04$ & \multicolumn{2}{|c|}{$6.63 \mathrm{E}-04$} \\
\hline & $\mathrm{H}_{0}:$ Pre $=$ Post & 7.31E-04 & \multicolumn{2}{|c|}{$-5.34 \mathrm{E}-04$} \\
\hline
\end{tabular}

Note: ${ }^{* * *}=$ significance at the $99 \%$ confidence level and N.A. = not applicable. The sample is from October 19, 2017, to July 18, 2019 (411 observations).

When the pre- and post-event windows are five days, the abnormal return is significant on the election day. It is not significant in the pre- and post-event windows. It is important to note that the post-election window covers the days on which the first and second unofficial election results were announced. The insignificant coefficient suggests that the announcements did not bring new information to the market.

The results are similar when the windows are expanded to 20 days. A positive surprise occurred and was fully revealed to the market only on the election day. The election is favorable to the market.

When the 20-day windows are divided into four sub-windows of five days, the average abnormal return on days +11 to +15 is significant and positive. The period is 10 trading days after the election; therefore, it is unlikely that the positive abnormal return is explained by the UIH. The 20-day post-event window is not long enough to cover the days the official results for the representatives were released. The study checked if there was any other possible significant sub-event occurring within that period and did not find any. Therefore, the study concludes that the significant coefficient for days +11 to +15 is spurious.

Finally, for the five-day and the 20-day window specifications, the hypothesis tests cannot reject the hypotheses of zero average abnormal return and equal average abnormal returns in the pre- and post-event windows.

\subsection{The Extended, Conditional Regression Approach}

The study estimated the extended conditional regression model in Equation (5). The results are reported in Column 3 of Table 4.

Table 4. Abnormal variables in the periods surrounding the election event and sub-events

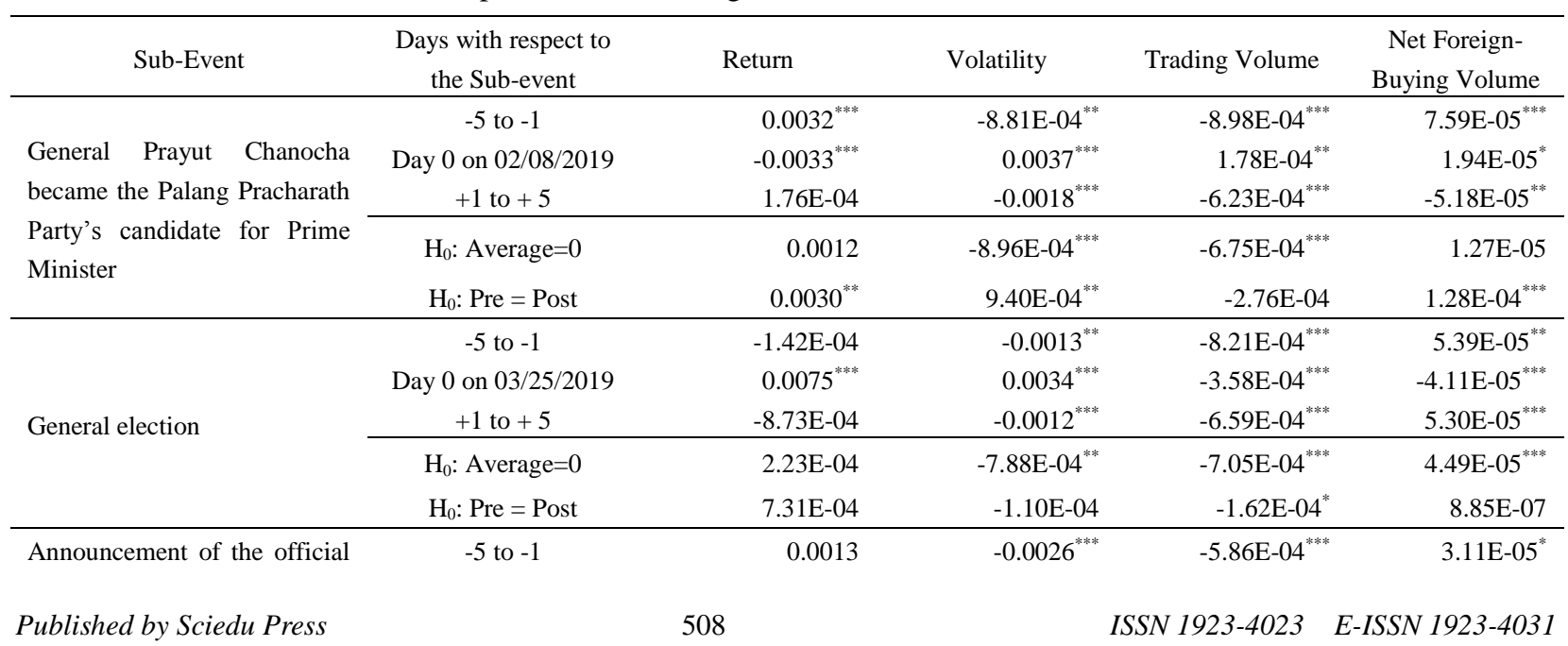




\begin{tabular}{|c|c|c|c|c|c|}
\hline \multirow{3}{*}{$\begin{array}{l}\text { results for constituencies and } \\
\text { party-list members of the } \\
\text { House of Representatives }\end{array}$} & $\begin{array}{c}\text { Day } 0 \text { on } 05 / 08 / 2019 \\
+1 \text { to }+5\end{array}$ & $\begin{array}{l}-0.0050^{* * *} \\
-0.0041^{* * *}\end{array}$ & $\begin{array}{r}-6.90 \mathrm{E}-04^{* * *} \\
-1.90 \mathrm{E}-05 \\
\end{array}$ & $\begin{array}{r}9.59 \mathrm{E}-05 \\
-3.34 \mathrm{E}-04^{* * *} \\
\end{array}$ & $\begin{array}{l}-5.36 \mathrm{E}-05^{* * *} \\
-3.80 \mathrm{E}-05^{* * *}\end{array}$ \\
\hline & $\mathrm{H}_{0}$ : Average $=0$ & $-0.0017^{* * *}$ & $-0.0013^{* * *}$ & $-4.10 \mathrm{E}-04^{* * *}$ & $-8.03 \mathrm{E}-06$ \\
\hline & $\mathrm{H}_{0}:$ Pre $=$ Post & $0.0055^{* * *}$ & $-0.0026^{* * *}$ & $-2.52 \mathrm{E}-04^{*}$ & $6.91 \mathrm{E}-05^{* * *}$ \\
\hline \multirow{5}{*}{$\begin{array}{l}\text { Chuan Leekpai was elected as } \\
\text { Speaker of the House of the } \\
\text { Representatives in the first } \\
\text { parliament session }\end{array}$} & -5 to -1 & -0.0013 & $-3.73 \mathrm{E}-04$ & $-1.58 \mathrm{E}-04^{*}$ & $6.42 \mathrm{E}-05^{* * *}$ \\
\hline & Day 0 on $05 / 25 / 2019$ & $0.0028^{* * *}$ & $-0.0015^{* * *}$ & $-9.81 \mathrm{E}-05$ & $3.84 \mathrm{E}-05^{* * *}$ \\
\hline & +1 to +5 & $8.17 \mathrm{E}-04$ & $-0.0011^{* * *}$ & $0.0020^{*}$ & $3.43 \mathrm{E}-04^{* * *}$ \\
\hline & $\mathrm{H}_{0}$ : Average $=0$ & $4.12 \mathrm{E}-05$ & $-7.86 \mathrm{E}-04^{* *}$ & 8.07E-04 & $1.88 \mathrm{E}-04^{* * *}$ \\
\hline & $\mathrm{H}_{0}:$ Pre $=$ Post & -0.0021 & $6.87 \mathrm{E}-04$ & $-0.0021^{*}$ & $-2.78 \mathrm{E}-04^{* * *}$ \\
\hline \multirow{5}{*}{$\begin{array}{l}\text { General Prayut Chanocha was } \\
\text { elected as Prime Minister in a } \\
\text { Joint Session of the House of } \\
\text { Representatives and the } \\
\text { Senate }\end{array}$} & -5 to -1 & 8.17E-04 & $-0.0011^{* * * *}$ & $0.0020^{*}$ & $3.43 \mathrm{E}-04^{* * *}$ \\
\hline & Day 0 on $06 / 05 / 2019$ & $0.0108^{* * *}$ & $-0.0026^{* * * *}$ & $1.91 \mathrm{E}-05$ & $3.42 \mathrm{E}-04^{* * *}$ \\
\hline & +1 to +5 & $0.0040^{* * *}$ & $-0.0016^{* * *}$ & $-5.09 \mathrm{E}-04^{* * *}$ & $1.29 \mathrm{E}-04^{* * *}$ \\
\hline & $\mathrm{H}_{0}$ : Average $=0$ & $0.0032^{* * *}$ & $-0.0015^{* * *}$ & $6.58 \mathrm{E}-04$ & $2.45 \mathrm{E}-04^{* * *}$ \\
\hline & $\mathrm{H}_{0}:$ Pre $=$ Post & $-0.0032^{* *}$ & 0.0006 & $0.0025^{* *}$ & $2.14 \mathrm{E}-04^{* * *}$ \\
\hline \multirow{5}{*}{$\begin{array}{l}\text { His Majesty the King } \\
\text { appointed the new cabinet, } \\
\text { according to the Royal } \\
\text { Gazette }\end{array}$} & -5 to -1 & -0.0011 & $9.43 \mathrm{E}-05$ & $6.31 \mathrm{E}-04^{* * * *}$ & $1.09 \mathrm{E}-04^{* * *}$ \\
\hline & Day 0 on $07 / 10 / 2019$ & $-0.0055^{* * *}$ & $-0.0019^{* * * *}$ & $9.33 \mathrm{E}-04^{* * * *}$ & $2.40 \mathrm{E}-04^{* * *}$ \\
\hline & +1 to +5 & $-2.63 \mathrm{E}-04$ & $-0.0012^{* * *}$ & $3.11 \mathrm{E}-04^{* *}$ & $1.14 \mathrm{E}-04^{* * *}$ \\
\hline & $\mathrm{H}_{0}$ : Average $=0$ & -0.0011 & $-6.82 \mathrm{E}-04^{* *}$ & $5.13 \mathrm{E}-04^{* * *}$ & $1.23 \mathrm{E}-04^{* * *}$ \\
\hline & $\mathrm{H}_{0}:$ Pre $=$ Post & $-8.40 \mathrm{E}-04$ & 0.0013 & $3.20 \mathrm{E}-04$ & $-5.30 \mathrm{E}-06$ \\
\hline \multicolumn{2}{|c|}{$\mathrm{H}_{0}$ : Different Mean in Event Window } & 0.0012 & $-0.0015^{* * *}$ & $-2.72 \mathrm{E}-04$ & $8.98 \mathrm{E}-05^{* *}$ \\
\hline
\end{tabular}

Note: ${ }^{*},{ }^{* *}$, and ${ }^{* * *}=$ significance at the $90 \%, 95 \%$, and $99 \%$ confidence levels, respectively. The sample is from October 19, 2017, to July 18, 2019 (411 observations).

Let us turn first to the election event. The results are almost exactly the same as those in Table 3 . These results are expected because most of the estimation samples of the two models overlap.

Their coefficients are significant for all events and sub-event days. The coefficients are significant for the pre-sub-event window for which Chanocha became the PPRP's candidate for PM and for the post-sub-event window for which the official results were released.

The hypothesis of zero average abnormal return is rejected for the sub-events of the PM candidacy of Chanocha, the announcement of official results, and the joint-session vote for PM Chanocha. The hypothesis of equal coefficients for the pre- and post-sub-event windows is rejected only for the latter two sub-events.

The results lead to the conclusion that the 2019 general election had significant effects on the SET. More importantly, there exists evidence to suggest that the pre- and post-election sub-events are significant. As the study proposes, the sub-events are significant and informative. Therefore, they cannot be excluded from the analysis.

\section{Discussion}

\subsection{Significant Events and Sub-events}

\subsubsection{Chanocha's Announcement of Candidacy for PM}

The five-day pre-sub-event window's abnormal return is positive and significant. This result can be explained by the UIH (Brown et al., 1998). It had been conjectured by many that Chanocha would become a politician and run for his second term for the PM position (Thongnoi, 2018). The information was more certain on January 30, 2019, when the PPRP invited Chanocha as its candidate for PM. Chanocha informed the public on February 7, 2019, that he would make his decision on February 8, 2019, that is, the -1 sub-event day. As more information was gradually disseminated to the public, the risk decreased and the stock price rose.

The coefficient for the sub-event day is negative and significant. This means that the market reacted negatively to Chanocha's decision. The negative impact could have reflected the public opinion that the election, with Chanocha running for the PM position, was unfair (Ellis-Petersen, 2019).

The abnormal return for the post-sub-event window is not significant. The market absorbed all the information about the decision on February 8, 2019. Therefore, there was no uncertainty after the day. However, the results are not consistent with those of Shaikh (2017). 


\subsubsection{The Election Day}

The pre- and post-election windows' abnormal returns are not significant. This may be explained by the fact that, once Chanocha ran for the PM position, it was almost certain that he had won it. The senators would vote for him, together with the representatives from the PPRP and its allies. The positive and significant abnormal return on the election-event day reflects the good news on the day. The election was peaceful. No violent public disturbances were reported (Kaewjinda, 2019).

\subsubsection{Release of the Results for Representatives}

The abnormal returns for the sub-event day and post-sub-event window are negative and significant. Although the outcome was official, it was not decisive. With respect to the pro-Chanocha Senate and the indecisive outcome, it was not clear which party would form the next government. The delay in forming the new government was interpreted by the market as increasing uncertainty and bad news. This result is similar to the one for the 2000 presidential election in the U.S. (Nippani \& Medlin, 2002).

\subsubsection{Leekpai as Speaker of the House of Representatives}

Only the abnormal return on the sub-event day is significant. It is positive, indicating that the sub-event was good news. Leekpai was from the Democratic Party, a major ally to the PPRP. The fact that Leekpai won the Speaker position indicates that the winning coalition was successfully formed. The uncertainty regarding which party would form the government was resolved (Shaikh, 2017).

\subsubsection{Chanocha's Victory for PM}

The abnormal returns are positive and significant for the sub-event day and post-sub-event window. The significance results are surprising. Earlier, the market reacted negatively to Chanocha's announcement of his PM candidacy. The uncertainty about which party formed the new government had been resolved by Leekpai's victory for the House Speaker position.

Although the election of Chanocha as PM was expected, the 251 majority votes that he received from the House of Representatives were important (Nanuam, 2019). Even without the senate, he could have won the PM position, thereby refuting the accusation against him of unfair election rules. Therefore, the positive and significant abnormal return for the post-sub-event window can be explained by reduced uncertainty and risk (Shaikh, 2017).

\subsubsection{The New Cabinet}

The abnormal return was negative and significant on the day the new cabinet was announced in the Royal Gazette. The market reacted negatively to this news. Some of the alliance parties were unsatisfied with being assigned no cabinet positions (Thaiger, 2019a). The representatives' votes were very close; therefore, a breakaway of even small alliance parties would have brought instability to the government (Brown et al., 1998; Shaikh, 2017).

\subsubsection{New Information on Event and Sub-event Days}

Event and sub-events should update new information; investors revise expectations and reallocate investment. This fact leads to significant abnormal variables. Although it had been conjectured that Chanocha would run for the PM position, he never admitted it. His announcement on February 8, 2019 is news to the market.

The election on Sunday, March 24, 2019 was the first election after the 2014 military coup. Because Chanocha ran for his second term, while he was the junta leader and PM of the incumbent government, the election was considered unfair (Ellis-Petersen, 2019). Violent protests on the election day were possible. It turned out the election was peaceful (Kaewjinda, 2019); the peaceful election was good news.

On May 8, 2019, the results for constituencies and party-list members of the House of Representatives were final after a long 45-day vote-counting and seat-calculating time. The election was a close election; the party-list seat calculation was not straightforward (Thai PBS WORLD, 2019); the difference only for a few seals determined which party won the election. News on the official results is important.

Because the election was very close, the negotiations among political parties were long and serious. The outcomes were unclear (Suhartono \& Ramzy, 2019). The fact that Leekpai won the Speaker position on May 25, 2019 was important news. Coalition was successfully formed.

Chanocha's win for the PM position was expected. The junta-appointed senators and coalition representatives' votes were enough, even if some parties defected from the coalition. His win was not news, but how he won it was. The negotiation among coalition parties continued even after Leekpai was elected as the House Speaker (Thaiger, 2019b). Defect was possible; the votes which Chanocha received from the representatives would not be majority votes; the 
accusation of unfair election rules would be substantiated (Lalit, 2019). The important news was the 251 majority votes Chanocha eventually received.

Finally, the announcement of new cabinet in Royal Gazette on July 10, 2019 brought news to the market. There were conflicts among factions in the PPRP over cabinet positions. On July 3, 2019, Chanocha informed the public that he had made the final decision on cabinet members without mentioning any name (Chetchotiros \& Nanuam, 1999).

\subsection{Other Stock-Market Performance Variables}

Previous election studies also considered other performance variables besides abnormal returns such as abnormal volatility (e.g., Bialkowski, Gottschalk, \& Wisniewski, 2008), market trading volume (e.g., Imelda et al., 2014), and net foreign-investor buying volume (e.g., Chiu, Chen, \& Tang, 2005). This study analyzes the effects of the 2019 election on these interesting performance variables and examines whether the inclusion of sub-events in the analyses is useful.

For the analyses, the variance is computed by Rogers and Satchell's (1991) adjusted extreme-value estimator. This estimator is efficient, simple, and general. The computation requires data on opening, closing, maximum, and minimum SET indexes readily observed during the day. Volatility is the square root of the variance. The market and net foreign-investor buying volumes are the volumes on the SET scaled by market capitalization. The opening, closing, maximum, and minimum indexes, as well as volumes and market capitalization, were retrieved from the SET database. The descriptive statistics are shown in Columns 3 to 5 in Table 2.

The study estimates Equation (5) for the three performance variables. The results are reported in Columns 4 to 6 in Table 4. The 2019 election had significant effects on the three variables. The coefficients are significant for all events and sub-events. The study concludes that the inclusion of sub-events in the analyses is useful.

\subsection{Uncertain Event Days}

The choice for event and sub-event days affects the conditional means and variances of performance variables and, as a result, the regressions of Equation (5) (Ball \& Torous, 1988). In this study, the uncertain-event-date problem may exist for the election day and the announcement day of the official results. For the election day, the second unofficial vote-counting result was on March 28, 2019, and the announcement of the official results was on May 7 and 8, 2019. To ensure that the problem does not affect the results, this study follows Ball and Torous (1988) to extend the event and sub-event days to windows of four and two days, respectively. The results are very similar to those in Table 4. Interested readers may obtain the results from the author upon request.

\subsection{Possible Structural Changes}

The election may induce structural changes so that the means of the performance variables for the estimation and event samples are different. In Equation (5), the term was added $\bar{\mu}^{\mathrm{W}} \mathrm{D}_{\mathrm{t}}^{\mathrm{W}}$ to account for possible differences. If there are structural changes, the coefficient $\bar{\mu}^{\mathrm{W}}$ is significant. In Table 4 , the coefficient is significant for the volatility and net foreign-investor buying volume.

\subsection{Confounding Effects}

In this study, the event window is 111 days from February 1, 2019, to July 18, 2019. The length is within the range from 21 to 120 days common to event study analyses (Peterson, 1989). However, confounding effects are possible (Nazir et al., 2014). To ensure that confounding effects are unlikely, the study checked for the events in details on all sub-event days and found that signs and significance of the ARs are consistent with the events and theoretical foundations. The discussion appears in Section 5.1 Significant Events and Sub-events.

\section{Conclusion}

A general election is not a single event; it comprises a series of sub-events that occur before, on, and after the election date. In election studies, therefore, event windows should cover all the sub-events and consider them individually in detail. This study extends the conditional regression model to be able to analyze the effects of specific sub-events.

The extended model is applied to estimate the effects of Thailand's 2019 general election on stock market performance. The results show that the effects are significant. The market reacted to new information pertaining to all sub-events. The inclusion of sub-events in the analysis is important and useful.

The proposed model is general and can be applied in most event studies. Examples include studies on regulatory changes (e.g., Lamdin, 2001) and military coups (e.g., Khanthavit, 2020). The model can be improved further in 
several directions, such as time-varying conditional mean (Khanthavit, 2020). This study leaves new applications and improvements for future research.

\section{Acknowledgments}

The author thanks the Faculty of Commerce and Accountancy, Thammasat University, for the research grant, the Stock Exchange of Thailand for stock-market variable data, and Chanya Siriarayaphan for research assistance.

\section{References}

Ahmed, W. M. A. (2017). The impact of political regime changes on stock prices: The case of Egypt. International Journal of Emerging Markets, 12(3), 508-531. https://doi.org/10.1108/JJoEM-12-2015-0258

Ball, C. A., \& Torous, W. N. (1988). Investigating security-price performance in the presence of event-date uncertainty. Journal of Financial Economics, 22(1), 123-153. https://doi.org/10.1016/0304-405X(88)90025-6

Bialkowski, J., Gottschalk, K., \& Wisniewski, T. P. (2008). Stock market volatility around national elections. Journal of Banking and Finance, 32(9), 1941-1953. https://doi.org/10.1016/j.jbankfin.2007.12.021

Brown, K. C., Harlow, W. V., \& Tinic, S. M. (1988). Risk aversion, uncertain information, and market efficiency. Journal of Financial Economics, 22(2), 355-385. https://doi.org/10.1016/0304-405X(88)90075-X

Brown, S. J., \& Warner, J. B. (1985). Using daily stock returns: The case of event studies. Journal of Financial Economics, 14(1), 3-31. https://doi.org/10.1016/0304-405X(85)90042-X

Butler, M. R., \& McNertney, E. M. (1991). Election returns as a signal of changing regulatory climate. Energy Economics, 13(1), 48-54. https://doi.org/10.1016/0140-9883(91)90055-5

Castells, P., \& Trillas, F. (2013). The effects of surprise political events on quoted firms: The March 2004 election in Spain. SERIEs, 4, 83-112. https://doi.org/10.1007/s13209-011-0080-5

Chandra, T. (2015). Impacts of Indonesia's 2014 presidential election towards Stock Priceso Indonesia Stock Exchange. International Journal of Business and Management, 10(7), 172-183. https://doi.org/10.5539/ijbm.v10n7p172

Chetchotiros, N., \& Nanuam, W. (1999, July 4). Govt finalises cabinet line-up. Bangkok Post. Retrieved from https://www.bangkokpost.com/thailand/politics/1706370/govt-finalises-cabinet-line-up

Chiu, C., Chen, C., \& Tang, W. (2005). Political elections and foreign investor trading in South Korea's financial market. Applied Economic Letters, 12(11), 637-677. https://doi.org/10.1080/13504850500190097

Ellis-Petersen, H. (2019, March 21). Thailand's first election in eight years won't be free or fair, say democracy activists. The Guardian. Retrieved from https://www.theguardian.com/world/2019/mar/22/thailands-first-election-in-eight-years-not-free-or-fair-say-de mocracy-activists

Fama, E. F., Fisher, L., Jensen, M. C., \& Roll, R. (1969). The adjustment of stock prices to new information. International Economic Review, 10(1), 1-21. https://doi.org/10.2307/2525569

Garfinkel, M. R., Glazer, A, \& Lee, J. (1999). Election surprises and exchange rate uncertainty. Economics and Politics, 11(3), 255-274. https://doi.org/10.1111/1468-0343.00061

Gemmill, G. (1992). Political risk and market efficiency: Tests based in British stock and options markets in the 1987 election. Journal of Banking and Finance, 16(1), 211-231. https://doi.org/10.1016/0378-4266(92)90086-F

Greene, R. (2018). Econometric Analysis (8th ed.). London: Pearson.

Hung, L. (2011). The presidential election and the stock market in Taiwan. Journal of Business and Policy Research, 6(2), 36-48. 20trieved from https://pdfs.semanticscholar.org/84e4/de2f07d4009856e8668c339c41c3c203947e.pdf

Imelda, I., Siregar, H., \& Anggraeni, L. (2014). Abnormal returns and trading volume in the Indonesian stock market in relation to the presidential elections in 2004, 2009, and 2014. International Journal of Administrative Science and Organization, 21(2), 65-76. https://doi.org/10.20476/jbb.v21i2.4319

Izan, H. Y. (1978). An empirical analysis of the economic effects of mandatory audit regulation. Unpublished Doctoral Dissertation, University of Chicago, Chicago. 
Kaewjinda, K. (2019, March 26). General elections were peaceful but not fair: Intl observer. Khaosod English. Retrieved from https://www.khaosodenglish.com/politics/2019/03/26/general-elections-were-peaceful-but-not-fair-intl-observer/

Khan, S., Jafri, R. A., Baig, N., Shaique, M., \& Usman, M. (2017). Stock index manipulation around election announcements: Evidence from Pakistan stock exchange. International Journal of Accounting and Economic Studies, 5(2), 87-91. https://doi.org/10.14419/ijaes.v5i2.7792

Khanthavit, A. (2020). A Kalman filtering approach to event study analysis when performance variables are nonstationary. Working paper, Faculty of Commerce and Accountancy, Thammasat University, Bangkok. Retrieved from https://www.researchgate.net/publication/334025651_A_Kalman_Filtering_Approach_to_Event_Study_Analys is_When_Performance_Variables_are_Nonstationary

Lalit, S. (2019, March 19). Thailand: Structural Flaws Subvert Election. Human Rights Watch. Retrieved from https://www.hrw.org/news/2019/03/19/thailand-structural-flaws-subvert-election

Lamdin, D. J. (2001). Implementing and interpreting event studies of regulatory changes. Journal of Financial Economics, 53(2-3), 171-183. https://doi.org/10.1016/S0148-6195(01)00035-2

Leblang, D., \& Mukherjee, B. (2005). Government partisanship, elections, and the stock market: Examining American and British stock returns. American Journal of Political Science, 49(4), 780-802. https://doi.org/10.1111/j.1540-5907.2005.00155.x

Lumjiak, S., Treepongkaruna, S., Wee, M., \& Brooks, R. (2016). Thai financial markets and political change. Journal of Financial Management, Markets and Institutions, 2(1), 5-26. https://doi.org/10.12831/77234

Maisrikrod, S. (2007). Learning from the 19 September coup: Advancing Thai-style democracy?. Southeast Asian Affairs, 2007, 340-359. https://doi.org/10.1355/SEAA07Q

Nanuam, W. (2019, June 6). PM Prayut thanks MPs for their votes, Bangkok Post. Retrieved from https://www.bangkokpost.com/thailand/politics/1690376/pm-prayut-thanks-mps-for-their-votes

Nazir, M. S., Younus, H., Kaleem, A., \& Anwar, Z. (2014). Impact of political events on stock market returns: Empirical evidence from Pakistan. Journal of Economic and Administrative Sciences. 30(1), 60-78. https://doi.org/10.1108/JEAS-03-2013-0011

Newey, W. K., \& West, K. D. (1994). Automatic lag selection in covariance matrix estimation. Review of Economic Studies, 61(4), 631-653. https://doi.org/10.2307/2297912

Niederhoffer, V., Gibbs, S., \& Bullock, J. (1970). Presidential elections and the stock market. Financial Analysts Journal, 26(2), 111-113. Retrieved from https://www.jstor.org/stable/4470664

Nimkhunthod, W. (2007). An impact of political events on the Stock Exchange of Thailand. Unpublished independent study, Faculty of Commerce and Accountancy, Thammasat University, Bangkok. Retrieved from http://www.openbase.in.th/files/seminar_jul9_weerasak.pdf

Nippani, S., \& Medlin, W. B. (2002). The 2000 presidential election and the stock market. Journal of Economics and Finance, 26(2), 162-169. https://doi.org/10.1007/BF02755983

Obradovic, S., \& Tomic, N. (2017). The effect of presidential election in the USA on stock return flow-A study of a political event. Economic Research-Ekonomska Istraživanja, 30(1), 112-124. https://doi.org/10.1080/1331677X.2017.1305802

Oehler, A., Walker, T. J., \& Wendt, S. (2013). Effects of election results on stock price performance: evidence from 1980 to 2008. Managerial Finance, 39(8), 714-736. https://doi.org/10.1108/MF-May-2012-0126

Panzalis, C., Stangeland, D. A., \& Turtle, H. J. (2000). Political elections and the resolution of uncertainty: The international evidence. Journal of Banking and Finance, 24(10), 1575-1604. https://doi.org/10.1016/S0378-4266(99)00093-X

Peterson, P. P. (1989) Event studies: A review of issues and methodology. Quarterly Journal of Business and Economics, 28(3), 36-66. Retrieved from www.jstor.org/stable/40472954

Redzwan, N., Musa, N., Latip A. H. A., Latif, Y. A., \& Rahman, I. N. A. (2019). Stock market analysis during election period in Malaysia. International Journal of Business and Economy, 1(2), 95-103. Retrieved from http://myjms.moe.gov.my/index.php/ijbec/article/view/7828 
Rogers, L. C. G., \& Satchell, S. E. (1991). Estimating variance from high, low, and closing prices. Annals of Applied Probability, 1(4), 504-512. https://doi.org/10.1214/aoap/1177005835

Salinger, M. (1992). Standard errors in event studies. Journal of Financial and Quantitative Analysis, 27(1), 39-53. https://doi.org/10.2307/2331297

Shaikh, I. (2017). The 2016 U.S. presidential election and the stock, FX and VIX. North American Journal of Economics and Finance, 42, 546-563. https://doi.org/10.1016/j.najef.2017.08.014

Suhartono, M., \& Ramzy, A. (2019, May 9). Thailand election results signal military's continued grip on power. The New York Times. Retrieved from https://www.nytimes.com/2019/05/09/world/asia/thailand-election-results.html

Tanakasempipat, P., \& Thepgumpanat, P. (2019, May 14). A third of Thailand's appointed senators linked to military, police. Reuters. Retrieved from https://www.reuters.com/article/us-thailand-election/a-third-of-thailands-appointed-senators-linked-to-militarypolice-idUSKCN1SK12J

Thai PBS WORLD. (2019, April 28). The EC will consider three formulae in party-list seat calculation. Thai PBS WORLD.

Retrieved

from https://www.thaipbsworld.com/the-ec-will-consider-three-formulae-in-party-list-seat-calculation/

Thaiger. (2019a). Thai coalition will meet with disgruntled MPs today. The Thaiger. Retrieved from https://thethaiger.com/hot-news/politics/thai-coalition-will-meet-with-disgruntled-mps-today

Thaiger. (2019b). Vote for new Thai PM on Wednesday-Democrats and Palang Pracharat still at loggerheads. The Thaiger. Retrieved

from https://thethaiger.com/hot-news/elections/vote-for-new-thai-pm-on-wednesday-democrats-and-palang-pracharat -still-at-loggerheads

Thongnoi, J. (2018, April 30). Thai junta likely to back another term for PM Prayut. The Straits Time. Retrieved from https://www.straitstimes.com/asia/se-asia/thai-junta-likely-to-back-another-term-for-pm-prayut

Wang, Y., Lee, M., \& Lin, C. (2008). General election, political change and market efficiency: Long- and short-term perspective in developed stock market. Journal of Money, Investment and Banking, 3, 58-67. Retrieved from https://www.researchgate.net/profile/Mei_Yu_Lee/publication/266372572_General_Election_Political_Change _and_Market_Efficiency_Long-and_Short-Term_Perspective_in_Developed_Stock_Market/links/550156660cf 2de950a722318/General-Election-Political-Change-and-Market-Efficiency-Long-and-Short-Term-Perspective-i n-Developed-Stock-Market.pdf

Wong, W., \& Hooy, C. (2016). The impact of election on stock market returns of government-owned banks: The case of Indonesia, Malaysia and Thailand. Asian Journal of Business and Accounting, 9(1), 31-58. Retrieved from https://ajba.um.edu.my/article/download/2725/922

World Federation of Exchanges. (2019). Statistics: Monthly Report. January 2020. Retrieved from https://focus.world-exchanges.org/issue/january-2020/market-statistics 